Abstracta Iranica

Revue bibliographique pour le domaine irano-aryen

Volume 23 | 2002

Comptes rendus des publications de $\mathbf{2 0 0 0}$

\title{
« Āyā MoHtār-nāme az 'Ațțār ast ? ». Našr-e Dāneš, 17, 1 (1379/2000), pp. 32-43.
}

\section{Charles-Henri de Fouchécour}

\section{(2) OpenEdition}

Journals

Édition électronique

URL : http://journals.openedition.org/abstractairanica/35807

DOI : 10.4000/abstractairanica.35807

ISSN : 1961-960X

Éditeur :

CNRS (UMR 7528 Mondes iraniens et indiens), Éditions de l'IFRI

Édition imprimée

Date de publication : 15 mai 2002

ISSN : 0240-8910

\section{Référence électronique}

Charles-Henri de Fouchécour, « «Āyā Mohtār-nāme az 'Atțār ast ? ». Našr-e Dāneš, 17, 1 (1379/2000), pp. 32-43. », Abstracta Iranica [En ligne], Volume 23 | 2002, document 272, mis en ligne le 08 février 2010, consulté le 25 septembre 2020. URL : http://journals.openedition.org/abstractairanica/35807 DOI : https://doi.org/10.4000/abstractairanica.35807

Ce document a été généré automatiquement le 25 septembre 2020.

Tous droits réservés 


\title{
« Āyā MoHtār-nāme az 'Atțār ast? ». Našr-e Dāneš, 17, 1 (1379/2000), pp. 32-43.
}

\author{
Charles-Henri de Fouchécour
}

1 Le MoHtāarr-nāme est un recueil célèbre d'environ 2.100 robāi $\bar{i}$-s (je dirais quatrains) divisés en 50 chapitres. L'ouvrage est divisé en cinquante chapitres, chacun consacré à un sujet. L'ensemble relève du domaine du soufisme littéraire. Le plus ancien manuscrit date de 731 h.q./1330. Ses défauts ont fait préférer un ms. daté de 826/1422 pour servir de base à l'édition qu'a réalisée de l'ouvrage Mohammad Reḍā Šafìi Kadkanī en 1358/1979 (Tehrān, Ṭūs, nº 199, LXX-300 p. ; 2 éd., 1375/1996). On connaît 18 copies du recueil. Il a toujours été attribué à Farīd al-Dīn 'Ațțār Nīšābūrī (ob. 586/1190), y compris par le savant éditeur, qui l'a aussi annoté. M. R. Šafi'ī Kadkanī a introduit le livre par une importante étude (pp. XXXVI-LXIV), en particulier sur le point de savoir ce qu'est le livre intitulé Hosrow-nāme. En effet, dans l'introduction au MoHtär-nāme, attribuée à 'Ațțār lui-même, ce livre est dit par celui-ci être de sa composition. Par une série d'arguments (résumés par S. 'A. Mīr-Afḍalī dans le présent article), Šafīīi Kadkanī montre que le titre de Hosrow-nāme désigne l'ouvrage célèbre de 'Ațțār, Elāhī-nāme, et non pas le roman d'amour qui n'a rien de soufi et qu'on a édité en l'attribuant avec toute la tradition à 'Ațtāar. Celui-ci n'a jamais donné le titre de Elāhī-nāme à son grand matnavī connu ensuite sous ce titre, où un roi et ses fils sont mis en scène. Le roman d'amour profane, lui, ne peut dater, comme il est montré, qu'au plus tôt de la fin du $8^{\mathrm{e}} /$ $14^{\mathrm{e}} \mathrm{s}$.

2 La difficulté abordée par l'article porte sur l'introduction au MoHtārr-nāme par l'auteur même du recueil et qui dit être 'Aț̣ār lui-même. Une longue polémique est engagée par S. 'A. Mīr-Afḍalī contre 'Abd al-Hoseyn Zarrīnkūb. Celui-ci, dans une série d'articles, a dit son doute absolu sur l'authenticité de l'œuvre en tant que telle. On ne peut résumer ici les arguments échangés, l'ensemble laissant l'impression de travaux encore peu aptes à de vraies comparaisons à divers points de vue entre le MoHtār-nāme et le reste de l'œuvre authentique de 'Ațtāar. L'un d'eux porte sur l'unité stylistique, l'autre sur 
l'ancienneté du texte, etc. Il reste un point sur lequel aucun des auteurs n'a insisté. Le compositeur de l'introduction déclare que ce recueil de quatrains (on en compte 2.279 dans l'édition) a été extrait du Dìvān même de 'Ațțār. Il est alors curieux qu'on n'ait encore retrouvé dans ce Dìvān que six quatrains du MoHtär-nāme.

INDEX

Thèmes : 11.1.1. Littérature persane classique

\section{AUTEURS}

CHARLES-HENRI DE FOUCHÉCOUR

Sorbonne Nouvelle - Paris III 